\title{
Sumatriptan and dihydroergotamine in proximal and distal human isolated coronary arteries
}

\author{
S Labruijere, MB Ramirez Rosas", R De Vries, AHJ Danser, A MaassenVanDenBrink \\ From The European Headache and Migraine Trust International Congress \\ London, UK. 20-23 September 2012
}

Sumatriptan and dihydroergotamine (DHE) are both 5-HT receptor agonists and two of the most widely used drugs for the acute treatment of migraine. These drugs are contra-indicated in people with cardiovascular disease because of their vasoconstricting properties, as has previously been assessed in proximal coronary arteries. The effect of DHE in distal coronary arteries, however, has never been reported, although smaller coronary arteries might also account for angina-like symptoms, especially in women. The aim of this study was to compare the contractile effects of sumatriptan and DHE in proximal and distal human coronary arteries, and to relate our findings to the plasma concentrations obtained in clinical practice. Segments of proximal $(\varnothing 3-5 \mathrm{~mm})$ and distal $(\varnothing 0.5-1$ $\mathrm{mm}$ ) human isolated coronary arteries were mounted in organ baths and concentration response curves for sumatriptan and DHE were constructed. In proximal coronary artery segments, maximal contractions to sumatriptan $(16+/-18 \%$ of contraction to $100 \mathrm{mM} \mathrm{KCl})$ and DHE $(5+/-$ $4 \%)$ were not significantly different. In contrast, in distal coronary arteries, the contractile responses to sumatriptan $(18+/-11 \%)$ were significantly larger than those to DHE $(4+/-2 \%)$. At clinically relevant concentrations (Cmax after different formulations), contractions to both sumatriptan and DHE in proximal as well as distal coronary arteries were below $6 \%$. Thus, our results indicate that coronary artery contractions to DHE in distal coronary artery are smaller than those to sumatriptan, although in the clinical situation both drugs are likely to induce only a slight contraction.

Published: 21 February 2013

\section{Reference}

1. MaassenVanDenBrink $A$, et al: Coronary side-effect potential of current and prospective antimigraine drugs. Circulation 1998, 98(1):25-30.
doi:10.1186/1129-2377-14-S1-P206

Cite this article as: Labruijere et al:: Sumatriptan and dihydroergotamine in proximal and distal human isolated coronary arteries. The Journal of Headache and Pain 2013 14(Suppl 1):P206.
Submit your manuscript to a SpringerOpen ${ }^{\circ}$ journal and benefit from:

- Convenient online submission

- Rigorous peer review

- Immediate publication on acceptance

- Open access: articles freely available online

- High visibility within the field

- Retaining the copyright to your article

Submit your next manuscript at $\boldsymbol{~ s p r i n g e r o p e n . c o m ~}$ 